Nemanja Veselinović ${ }^{1}$

Bojan Krstić ${ }^{2}$

University of Niš, Faculty of Economics

Martina Veselinović ${ }^{3}$

Ibis Instruments Ltd.
P. $1-17$

ORIGINAL SCIENTIFIC PAPER

DOI: $10.5937 / \mathrm{ESD} 2102001 \mathrm{~V}$

Received: January 25, 2021

Accepted: March 28, 2021

\title{
MEASURING THE EFFICIENCY OF HUMAN CAPITAL
}

\begin{abstract}
Increased efficiency is a necessity for any company in the knowledge-based economy, rather than an option, in the circumstances of constant change and global competition. The efficiency of using resources, especially intellectual resources, is a crucial factor in assessing the financial strength of an enterprise. Since intellectual resources are immaterial and mainly invisible, measuring and managing them is difficult. Measuring human capital efficiency provides relevant information for management, as human capital significantly affects a company's performance. The aim of the paper is to explain the importance of measuring human capital efficiency through selected conventional and contemporary indicators. This paper will show what managerial information we could get thanks to the quantification of human capital efficiency in using the specific indicators in the labour productivity analysis.
\end{abstract}

Key words: human capital, measurement, efficiency, performance

JEL classification: $M 21$

\section{МЕРЕЊЕ ЕФИКАСНОСТИ ХУМАНОГ КАПИТАЛА}

\section{Апстракт}

У околностима сталних промена $и$ глобалне конкуренције повећана ефикасност постаје неопходност за било коју компанију у економији заснованој на знану, а не опщија. Ефикасност употребе ресурса, посебно интелектуалних ресурса, пресудан је фактор у проиени економске снаге организаиије. Будући да су интелектуални ресурси нематеријални и, углавном, “невидљиви”, мерење и управљање њима је тешко. Мерење ефикасности људског капитала пружа релевеантне информације за менаимент, јер људски капитал знатно утиче на перформансе компаније. Циљ овог рада је истииање значаја мерења ефикасности ьудског капитала кроз одабране традиционалне и савремене показатеље. Овај рад ће показати које упрвљачке информаиије можемо добити захваљујући квантификаиији ефикасности људског капитала приликом коришћења одређених показатеља у анализи продуктивности.

Кључне речи: људски капитал, мерење, ефикасност, перформансе

\footnotetext{
${ }^{1}$ nemanjaveselinovic@gmail.com, ORCID ID 0000-0001-7254-3870

${ }^{2}$ bojan.krstic@eknfak.ni.ac.rs, ORCID ID 0000-0003-4597-6819

${ }^{3}$ martinaveselinovic@gmail.com, ORCID ID 0000-0002-2396-6997
} 


\section{Introduction}

Productivity is a universal phenomenon of macro and microeconomic theory and practice. Productivity is an indicator of the efficiency of the use of human capital, i.e. work of people (employees) in the company. In the literature in the field of macroeconomics and microeconomics, there are different concepts of productivity: labour productivity, capital productivity, labour and capital productivity, human capital productivity. In further discussions of productivity management, the emphasis is mainly on the concept of labour productivity, i.e. productivity in the use of human and other intellectual resources.

Productivity as an economic principle is a requirement to achieve certain production volume with minimal labour costs (Krstić \& Sekulić, 2020). One of the primary goals in the system of goals of a company is the achievement of optimal labour productivity. Success in achieving this goal is controlled and monitored based on labour productivity measures. Labour productivity, as a measure of performance, quantifies economic success in the production of human labour, i.e. human resources of the enterprise.

The essence of labour productivity is in the production, that is, economic activities of the company which are determined by the possibilities of meeting consumer needs. Following the realization of the basic economic principle (to achieve maximum economic results with the minimal usage of resources), it is of interest to achieve as extensive a range as possible between the volume production and the labour consumption (working hours). This labour productivity indicator has a non-financial character.

In the new circumstances introduced by the era of the knowledge economy, human and other intellectual resources are treated as a vital, even strategic resource of a company. Due to the increased importance of intellectual resources for the competitiveness of the contemporary enterprise, there is more and more talk about the need to increase the productivity of human and, especially, other intellectual resources.

These moments influence the change of traditional economic terminology and the spread of the concept of productivity in terms of methodological apparatus of labour efficiency measurement and control. In addition to non-financial productivity measurement, the emphasis is also on the financial productivity measurement. Namely, it is about the concept of efficiency of the use of human capital. In that sense, the point is to achieve as extensive a range as possible between the achieved results (human capital value added resulting from the use of human capital) and the value of invested human capital. In this way, a specific human capital productivity (efficiency) indicator was obtained.

Human capital is, in fact, human resources. In today's competitive environment and the information (digital) age, intellectual capital is an exceptional source of creating and maintaining the competitive advantage of companies (Krstić, 2007). Therefore, there is a managerial obligation to intensify time and energy in managing human and other intellectual resources, i.e. to manage productivity in the right way.

\section{Human capital}

Bontis and Fitz-enz classify intellectual capital into three categories: "human capital, structural capital and relational capital" (Bontis \& Fitz-enz, 2002). As different views on defining human capital exist, Bontis and Fitz-enz (2002) state that human capital represents 
the pure intelligence, knowledge, talent, experience of the employees and an essential constituent of the intellectual capital.

Chen and Lin (2004) identified three approaches to the definition of human capital. The first approach is the transaction cost economy theory, where companies can employ a new worker from inside or outside of the company. Since both options have their costs, companies will always choose the cheaper option, representing the most efficient way. The second approach is the resource-based view of the company, where the human competences that make up the essence of the business and build a competitive advantage must be developed within the company. The third approach is the human capital theory, where companies make decisions about investments in human capital by evaluating potential future benefits.

Fitz-enz (2010) describes human capital as a set of permanently and occasionally employed workers. The question is how much companies want to keep or lose certain employees. With the departure of employees from the company, the company itself loses part of the human capital in which it has invested a certain amount of money. Cascio (2010) states that talent is the potential of employees, who are currently part of an enterprise or who might come later. Furthermore, this potential of employees includes the realization of their capacities.

The investment in human capital can allow an enterprise to gain a competitive advantage and represent an input that companies transform into talents and technology (Porter \& Stern, 2001). The capacities of employees represent the company's asset, and that is one of the reasons for investing in employees. Ruchala (1997) stated that by investing in human capital, a company would improve the efficiency and quality of products/services, and differentiation.

Human capital is described as a collection of basic characteristics and properties of workers and serve as a source of potential benefits and profits for both the employee and the company that employs this capital under certain conditions (Pocztowski, 2003, p. 45). Knowledge is the most valuable asset and knowledge management is critical to a firm's success (Oviedo-Garcia et al., 2014). Therefore, human capital investments could boost labour productivity and financial performances of an enterprise (Black \& Lynch, 1996).

Durrani and Forbes (2003) state that investments in human resources and IT are strongly connected to business success. Nafukho et al. (2004) point out that investing in human assets results in increased employees' performance, productivity and economic development of an enterprise. Since human capital is the main strength (Sajkiewicz, 2002, p. 17) and affects business performance, human capital measurement and control are necessary. Since human capital is a complex phenomenon, this paper focuses on the following dimension - the measurement of human capital efficiency and indicators which allow managers to control the results of human capital.

\section{Human capital measurement and reporting}

The human capital of an enterprise is defined as individuals who are constantly bound to the enterprise and its mission, can collaborate and have creative attitudes and high-quality qualifications (Bagieńska, 2015). Unlike authors who have used the term investments in the employee, some authors have used the term human capital, obliquely suggesting that an employee with human capital is of some value for an organizational (business) unit within an enterprise or an enterprise as a whole (Cambpell, Coff \& Kryscynsky, 2012). People who are part of the enterprise are indeed one of the key drivers of attaining financial results. It is often stated that human capital is the key to the development of an enterprise and that employees 
are vital assets in terms of competitiveness and business performance. Furthermore, human capital is described as a base for gaining the potential future profit (Kozińska, 2003).

Folloni and Vittadini (2010) see human capital as a complex phenomenon with numerous intangible dimensions. They find all these intangible dimensions very challenging to be observed and measured with precision. An enterprise can manage people, as one of its core resources, by measuring human capital. Some studies suggest that enterprises that do not deal with the measurement of their human capital may miss business opportunities to generate long-term and sustainable results.

Naden (2019) emphasized the relevance of human capital efficiency measurement because of the high percentage (up to 70\%) of workforce costs in the total expenses. Enterprises must have a clear perception of the real power of their employees. The main benefits of human capital measurement are reflected in a better understanding and maximization of the employees' impact and contribution to long-lasting accomplishments. Additionally, enterprises should develop adequate competitiveness strategies based on the human capital indicators and implement them by data-driven decisions for their further improvement.

Human capital represents the economic value of workers' education and skills, and include resources such as education, training, intelligence, skills, talents, health, etc. Given that human capital can be expressed through all investments and costs for employees (salaries, benefits, education, training, etc.), the formula for human capital $(H c)$ is as follows (Krstić \& Bonić, 2016):

$$
H c=P e+S i,
$$

where Pe stands for personal expenses and Si for the total sum of stimulating incentives. Generally, $P e$ includes expenses for employees or salaries of employees and managers (net salary + payroll taxes), plus investments in human resources development, such as education, training costs, etc.

By improving human capital management, we can expect an increase of over $20 \%$ of the market value of an enterprise (Marcinkowska, 2004). The study by Ocean Tomo LLC specified "that the share of intangible assets in the market value of the S\&P 500 share index enlarged from $17 \%$ to $90 \%$ in the period from 1975 to 2020 ", suggesting that workers represent a key source of these intangible assets. According to ISO 30414, 4C Consulting Group emphasized four fields of major benefits of reporting on human capital (Mauterer \& Wengel, 2019):

1) Reporting on human capital can contribute to the field of investors and the capital market through a precise assessment of a company and its upcoming sustainability;

2) Reporting on human capital can contribute to the field of politics through transparency on the labour market and attractiveness of economies;

3) Reporting on human capital can contribute to the field of enterprises through the identification of HR-related strengths and weaknesses, as well as the evaluation of costs and investments of development potentials of the employees;

4) Reporting on human capital can contribute to the area of potential applicants through insights into the dealing with workforce and evaluation of career opportunities.

Issues regarding the measurement approach were recognized by Abasilim and Agboola (2013) in: a) the form of leading financial or other retrospective indicators, b) inability to measure all contributory aspects to the human capital added value, c) inattentiveness about assets growth, d) a focus on short-term instead of long-term goals. Price (2011) noted that 
workers are frequently not pleased with the performance measurement and performance management systems. Regarding their confrontational nature, managers are often unwilling to take part in the performance measurement process.

Baron (2017) identified three dimensions of the human capital measurement: 1) the measurement of efficiency of HR department, 2) the measurement of effectiveness of work processes, 3) the measurement of the return on investment in key work processes. Kucharčíková, Tokarčíková and Durišová (2015) stated that the human capital productivity measurement could lead to the level of attainment of a target (increase customer satisfaction or revenues, shorten the time for complaint handling, etc.), quantification of company gains, the amount of financial result per employee, etc.

K.E. Sveiby is the first author who introduced the intellectual capital measurement concept (Borowski, 2015). It consists of the introduction of the scorecard of an enterprise, classification of intangible assets (three categories), presentation of financial (fourth category) and other forms of indicators (non-financial), as well as indicators in a distinct addition and usage of constant traditional financial measurement methods.

There are two broad perspectives that Giménez, López-Pueyo and Sanaú (2015) used for the classification of human capital measurement: the quantitative and qualitative perspective. The quantitative perspective approach comprises studies based on measuring the level of formal education, the cost of human capital investment and differences in the salary regarding different educational levels. On the other hand, the qualitative perspective approach highlights the differences in the quality of the level of qualifications and training. To quantify the level of qualifications, this approach uses the criterion of educational inputs.

\section{Measuring the economic efficiency of human capital usage}

In this paper, the focus is on measuring human capital efficiency. Efficiency is defined as the ratio of achieved outputs and inputs, and their interpretation can be different (Kucharčíková, Tokarčíková \& Durišová, 2015). Therefore, human capital efficiency is calculated as the quotient of the volume of output and the value of human capital.

Borowski (2015) defined human capital efficiency (HCE) as the efficiency rate in the use of human capital, which is an indicator of human capital importance in terms of the value added creation in the company:

$$
H C E=\frac{V A}{H C},
$$

where $V A$ stands for value added, which is calculated by adding salaries to operating profit (Krstić \& Sekulić, 2020) and HC stands for salaries and other expenditure incurred for the company's workforce.

Intending to measure human capital efficiency, Rahim, Atan and Kamaluddin (2017) conducted a study in which they applied Pulićs Value Added Intellectual Coefficient $\left(V A I C^{T M}\right)$ methodology (Pulić, 2000). In this study, a significant and positive relationship between human capital efficiency and company performance was determined. VAIC ${ }^{\mathrm{TM}}$ methodology has been used extensively by many researchers (Chen et al., 2005; Kamath, 2007; Chan, 2009; Ghosh \& Mondal, 2012). According to them, the major benefit of using this methodology is the provision of quantifiable, unbiased and quantitative measurements. Also, there is no requirement for any subjective grading. The methodology is of great use for not only further calculation but also statistical analysis of a large sample size of data items gathered over time. Another benefit of using VAIC ${ }^{\mathrm{TM}}$ methodology for the measurement 
of human capital efficiency is the utilization of simple and straightforward procedures to compute required indexes and coefficients.

Kujansivu and others (2007, p. 159) define metrics and indicators as essential management tools that allow the control of multipart phenomena by summarizing the outcomes in the form of figures. By using metrics and indicators, these multipart phenomena could be controlled at certain levels or, on the other hand, their actions might be impossible to be directed. The measurement is necessary for various reasons and its usage depends on the need of the company. Indicators provide precise information about the company to the management. Therefore, they could be used to control the achievement of previously set goals. Additionally, Kujansivu and others (2007, p. 160) stated that a company could make the most of measurement by using metrics and indicators to back up the decision-making process, question modes of operations, set the compensation base, envision the business development, etc.

Efficiency in the use of human capital $(E h c)$ is an indicator of the productive use of human capital by the company. The human capital efficiency indicator is calculated as follows (Krstić \& Bonić, 2016):

$$
E h c=\frac{I C V A}{H C} .
$$

Earnings before interest and taxes (EBIT) are adjusted to obtain this indicator. Intellectual capital value added (ICVA) represents the amount of newly created value per monetary unit invested in visible intellectual capital (Dženopoljac, 2013, p. 134). In essence, this indicator represents the return on intangible assets and goodwill. ICVA is obtained as follows (Krstić \& Bonić, 2016):

$$
I C V A=E B I T+D f a+A m i a+I m l+P e,
$$

or

$$
I C V A=E B I T D A+P e,
$$

where $D f a$ refers to the depreciation of fixed or long-term assets, and Amia refers to the amortization of intangible assets with an identified lifespan. $I \mathrm{ml}$ refers to a decrease in the value of intangible assets with an indefinite lifespan (goodwill). EBITDA represents earnings before interest, taxes, depreciation and amortization.

\section{Labour productivity and other human capital indicators}

The methodological issue of measuring labour productivity is characterized by multidimensionality and complexity. It derives from the very essence of productivity, as well as from the information base for measuring productivity. Labour productivity $(\mathrm{P})$ is measured as the quotient between the production volume (Q) and labour consumption (L) (Krstić \& Sekulić, 2020):

$$
P=\frac{Q}{L} \text {. }
$$

When determining the total labour consumption L (for a company or a narrower organizational unit, in which employees of different qualifications work), it is necessary to recalculate labour consumption (in working hours) of different qualification (Ll) based on 8 different coefficients of work complexity $\left(\mathrm{Cql}_{\mathrm{a}}, \mathrm{Cql}_{\mathrm{b}}, \mathrm{Cql}_{\mathrm{c}}, \mathrm{Cql}_{\mathrm{d}}, \mathrm{Cql}_{\mathrm{e}}, \mathrm{Cql}_{\mathrm{f}}, \mathrm{Cql}_{\mathrm{g}}, \mathrm{Cql}_{\mathrm{h}}\right)$. This is usually the simplest work - work of the lowest degree of complexity, which we obtain by 
multiplying the work of a certain complexity by the appropriate coefficient for that level of complexity (qualification) of work: $\mathrm{Lll}=\mathrm{Ll} \mathrm{x} \mathrm{Cql}$ where $\mathrm{Cql}_{\mathrm{a}}$ denotes the equivalent of the simplest work (the first degree of complexity - a). By expressing the labour consumption of different qualifications of employees through the equivalent of the simplest work, we obtain the total labour consumption of employees of one organizational unit or company as a whole. More precisely, the basic labour productivity formula then takes the following form (Krstic \& Sekulić, 2020):

$$
P=\frac{Q}{L l} \text {. }
$$

Also, the production volume (Q) in the above-mentioned formula could be expressed in different categories - income, costs, cash flow. In addition to the basic productivity formula, other productivity formulas of financial nature could be obtained. With this in mind, we can discuss:

- Non-financial (natural) aspect of measuring labour productivity;

- Financial aspect of measuring labour productivity.

The basic labour productivity formula reflects the non-financial (natural) is used for measuring the productivity of a particular organizational unit (production plant, department, etc.), as well as the productivity of a company. It is especially suitable for measuring productivity in the production of different products.

When a company produces a range of products, the application of the basic formula has a limitation because the total production of products of different use-value or expressed in different measurement units cannot be aggregated. In that case, we use the special methodology of the conditional product, where the produced quantity of different products from the assortment is recalculated to the quantity of the product marked as conditional. Namely, this specific methodological procedure first leads to the production expressed in the conditional product units $(\mathrm{Qu})$. Then it is placed in relation to the labour consumption in the production process (L) and determines labour productivity (Krstić \& Sekulić, 2020):

$$
P=\frac{Q u}{2},
$$

that is, if the labour consumption $\left(\mathrm{L}_{1}, \mathrm{~L}_{2}, \mathrm{~L}_{3}, \ldots, \mathrm{L}_{\mathrm{x}}\right)$ of different employees $(\mathrm{x}=1$, $\ldots, \mathrm{n})$ with differentiated degrees of qualification $\left(\mathrm{Cql}_{\mathrm{a}}, \mathrm{Cql}_{\mathrm{b}}, \mathrm{Cql}_{\mathrm{c}}, \mathrm{Cql}_{\mathrm{d}}, \mathrm{Cql}_{\mathrm{e}}, \mathrm{Cql}_{\mathrm{f}}\right.$, $\left.\mathrm{Cql}_{\mathrm{g}}, \mathrm{Cql}_{\mathrm{h}}\right)$ is expressed through the same measure - the simplest work of the so-called first degree of work $\left(\mathrm{Cql}_{\mathrm{a}}\right)$ complexity, the following formula is obtained (Krstić \& Sekulić, 2020):

$$
P=\frac{Q u}{L l} \text {. }
$$

Ll denotes the labour consumption of employees of different levels of qualification, calculated and expressed in the equivalents of the simplest work, with the lowest level of complexity. It is a job for which only primary school has been completed by the employee. This kind of productivity measurement has a non-financial nature.

The financial aspect of measuring labour productivity implies that the measurement uses categories expressed in monetary terms, and the data from the balance sheet and income statement serve as an information basis. The reason for that is overcoming the information limitations of the non-financial aspect of labour productivity measurement. The financial aspect of measurement implies several different productivity indicators.

First, labour productivity is the ratio of total revenue (R) and labour consumption (L) (Krstić \& Sekulić, 2020): 


$$
P=\frac{R}{L} \quad \text { or } P=\frac{R}{L l} \text {. }
$$

This formula overcomes the problem of expressing products of different use-value or expressed in different quantitative units of measure because the total production of the company is expressed in value - income.

Very often, in practice, by applying the financial concept, labour productivity is measured as operating revenue (Ro) per employee (Krstić \& Sekulić, 2020), so we get the following productivity indicator:

$$
P=\frac{\text { Ro }}{\text { Number of employees }},
$$

or the productivity indicator - sales (S) per employee:

$$
P=\frac{s}{\text { Number of employees }} \text {. }
$$

This productivity indicator can also be designed as total expenses (E) per employee (Krstić \& Sekulić, 2020):

$$
P=\frac{E}{\text { Number of employess }},
$$

which is also often encountered in practice.

The measuring expression of labour productivity which represents the quotient of profit (P) and labour consumption (L, i.e. Ll) (Krstić \& Sekulić, 2020):

$$
P=\frac{P}{L},
$$

does not adequately measure productivity in terms of product expression and change. We should keep in mind the shortcomings of such a determined expression, which are a consequence of the presence of prices (products and consumption of production elements) in the realized profit, whose dynamics can otherwise deform the accurate picture of realized productivity in two consecutive periods. In other words, qualitative and quantitative changes in products are not adequately expressed through the profit size. In practice, on the other hand, by applying the financial concept, productivity is often measured as operating profit (Op) per employee (Krstić \& Sekulić, 2020):

$$
P=\frac{P o}{\text { Number of employess }} \text {. }
$$

Then, productivity indicator as net profit (Pn) per employee (Krstić \& Sekulić, 2020):

$$
P=\frac{P n}{\text { Number of employess }},
$$

but also as economic profit, i.e. economic value added (EVA) per employee (Human Economic Value Added - HEVA) (Meszek, 2015; Krstić \& Sekulić, 2020):

$$
P=\frac{\text { EVA }}{\text { Number of employess }} \text {. }
$$

In more modern literature, we also find a productivity measure with cash flow (Cf) in the numerator, so we get cash flow per employee. This kind of productivity measurement ensures that the measurement is less dependent on accounting principles relevant for determining accounting profit. The measure of cash flow per employee is important for productivity analyses because it is recalculated to determine the difference in the contribution 
of labour (average employee) to the cash flow of the company or organizational (business) unit. Namely, this measure shows how much cash flow was generated by each employee. This indicator quantitatively results from the multiplication of the following indicators: cash flow margins and labour productivity in which the production is expressed in terms of sales revenue or, even more comprehensively, revenue (Buhner, 1997):

$$
\frac{c f}{\text { Average number of employess }}=\frac{c f}{\text { Sales revenue }} \cdot \frac{\text { sales revenue }}{\text { Average number of employess }} \text {, }
$$

or

$$
\frac{c f}{\text { Average number of employees }}=\frac{c f}{\text { Revenue }} \cdot \frac{\text { Revenue }}{\text { Average number of employees }} \text {. }
$$

Human capital cost factor (HCCF) reflects the total cost of human capital (Drábek et al., 2017). Fitz-enz (2000, p. 46-47) believes that this indicator is based on calculating four main types of human capital costs: salary and benefit costs for employees, contingencies, absence costs and turnover costs. Krstić \& Bonić (2016) stated that human capital cost factor (HCCF) is equivalent to the category of human capital (Hc). This category includes salaries for managers and other employees, as well as the total sum of stimulating incentives for managers, so it is calculated as follows (Krstić \& Bonić, 2016):

$$
\mathrm{HCCF}=\mathrm{Pe}+\mathrm{Si}=\mathrm{Hc}
$$

or HCCF per employee:

$$
\text { HCCF per employee }=\frac{H c}{\text { Number of employess }},
$$

or

$$
\text { HCCF per employee }=\frac{p_{e}+S i}{\text { Number of employess }} \text {. }
$$

Human capital market value (HCMV) provides information on a company's net market value per employee (Drábek et al., 2017, p. 123). Human capital market value is calculated as follows (Drábek et al., 2017, p. 123):

$$
H C M V=\frac{M c: A s}{\text { Number of employees }},
$$

where $M c$ refers to market capitalization and $A s$ denotes total assets in the balance sheet. Human capital market value is also calculated as follows (Drábek et al., 2017, p. 123):

$$
H C M V=\frac{T \text { obin's } Q}{\text { Number of employees }},
$$

where Tobin's Q is the ratio of the market value of a company's assets and replacement value of a company's assets (Lindenberg \& Ross, 1981).

Human capital value added (HCVA) is an indicator for measuring human capital productivity that explains productivity from a profitability perspective (Fitz-enz, 2000, p. 50). This indicator reflects the economic efficiency of human capital in the enterprise through the full-time equivalent in value added (Drábek et al., 2017, p. 123). Human capital value added is calculated as follows (Fitz-enz, 2000, p. 50):

$$
\text { HCVA }=\frac{\text { Revenue }-(\text { Expenses }- \text { Pay and benef its })}{\text { Full-time equivalent }},
$$


or

$$
H C V A=\frac{E B I T+H c}{\text { Number of employess }} .
$$

Human capital return on investment (HCROI) is an indicator that shows the relationship between human capital and profitability (Drábek et al., 2017, p. 123). This indicator represents the return on investment in human capital in the form of profit for the money spent on employee salaries and benefits (Fitz-enz, 2000, p. 50). Human capital return on investment is calculated as follows (Fitz-enz, 2000, p. 50):

$$
\text { HCROI }=\frac{\text { Revenue }-(\text { Expenses }- \text { Pay and benef its })}{\text { Pay and benefits }},
$$

or

$$
H C R O I=\frac{E B I T+H C}{H C} .
$$

\section{Measuring human efficiency: the case of UPS}

This research includes the use of secondary financial data from annual reports and the case study method to apply human capital efficiency indicators to the same data. The UPS serves as an example for analysing the efficiency of human capital and using the obtained information to benefit the company's management. Although UPS is not a knowledge company, it was taken as an example because it operates successfully and is ranked as one of the most successful companies. The measurement and management of human capital are critical in all kinds of companies, whether they are knowledge companies or not. Also, UPS's financial statements fully provide the necessary data to conduct the analysis, so this company is considered an appropriate example.

The data are taken from the annual reports of the company UPS in 2017, 2018 and 2019. The necessary information for calculating human capital efficiency indicators can be found in the company's balance sheet and income statement. Information on the total amount of stimulating incentives is taken from the proxy statement of the company UPS in 2018, 2019 and 2020. The aim of the research is the possibility of practical use and control of human capital efficiency indicators in companies, primarily due to the great influence of human capital on the results of the company, the control of the efficiency of the use of human capital and the improvement of the results.

United Parcel Service (UPS) is an American multinational company headquartered in the American city of Sandy Springs, Georgia. UPS deals not only with package delivery and supply chain management but also with cargo airline, freight-based trucking operations, delivery drone airline, customs brokerage, mail and consulting services. It provides services in more than 175 countries and territories worldwide. Also, UPS was on the Best Global Brands 2019 Rankings and the 2019 Fortune 500 list of the largest United States corporations by total revenue.

To determine indicators of human capital efficiency, certain financial information from the annual reports is necessary. The consolidated balance sheet of UPS is presented in Table 1. UPS is not a knowledge enterprise, which can be explained by the ratio of intangible assets and goodwill ( $\mathrm{Iag}$ ) in the assets' value (As). Thanks to financial information presented on a consolidated balance sheet in 2019 , this ratio is calculated and shows that only $10.34 \%$ of total assets are intangible assets. 
Table 1. Consolidated Balance Sheet of UPS as of December 31, 2017, 2018 and 2019

\begin{tabular}{|c|c|c|c|c|c|c|c|}
\hline ASSETS & $\begin{array}{c}2017 \\
\text { (In \$ } \\
\text { million) }\end{array}$ & $\begin{array}{c}2018 \\
\text { (In \$ } \\
\text { million) }\end{array}$ & $\begin{array}{c}2019 \\
\text { (In \$ } \\
\text { million) }\end{array}$ & LIABILITIES & $\begin{array}{c}2017 \\
\text { (In \$ } \\
\text { million) }\end{array}$ & $\begin{array}{c}2018 \\
\text { (In \$ } \\
\text { million) }\end{array}$ & $\begin{array}{c}2019 \\
\text { (In \$ } \\
\text { million) }\end{array}$ \\
\hline $\begin{array}{l}\text { I Current } \\
\text { assets }\end{array}$ & 15,718 & 16,210 & 17,103 & $\begin{array}{l}\text { I Current } \\
\text { liabilities }\end{array}$ & 12,886 & 14,087 & 15,413 \\
\hline $\begin{array}{c}\text { Cash and cash } \\
\text { equivalents }\end{array}$ & 3,320 & 4,225 & 5,238 & $\begin{array}{l}\text { Current maturities } \\
\text { of long-term debt } \\
\text { and commercial } \\
\text { paper }\end{array}$ & 4,011 & 2,805 & 3,420 \\
\hline $\begin{array}{l}\text { Marketable } \\
\text { securities }\end{array}$ & 749 & 810 & 503 & $\begin{array}{l}\text { Current maturities } \\
\text { of operating leases }\end{array}$ & - & - & 538 \\
\hline $\begin{array}{c}\text { Accounts } \\
\text { receivable, net }\end{array}$ & 8,773 & 8,958 & 9,552 & Accounts payable & 3,934 & 5,188 & 5,555 \\
\hline $\begin{array}{c}\text { Current } \\
\text { income taxes } \\
\text { receivable }\end{array}$ & 1,573 & 940 & 382 & $\begin{array}{l}\text { Accrued wages } \\
\text { and withholdings }\end{array}$ & 2,608 & 3,047 & 2,552 \\
\hline $\begin{array}{l}\text { Other current } \\
\text { assets }\end{array}$ & 1,303 & 1,277 & 1,428 & $\begin{array}{l}\text { Self-insurance } \\
\text { reserves }\end{array}$ & 705 & 810 & 914 \\
\hline & & & & $\begin{array}{l}\text { Accrued group } \\
\text { welfare and } \\
\text { retirement plan } \\
\text { contributions }\end{array}$ & 677 & 715 & 793 \\
\hline & & & & $\begin{array}{l}\text { Other current } \\
\text { liabilities }\end{array}$ & 951 & 1,522 & 1,641 \\
\hline $\begin{array}{c}\text { II Non-current } \\
\text { assets }\end{array}$ & & & 40,754 & $\begin{array}{l}\text { II Non-current } \\
\text { liabilities }\end{array}$ & & & 39,161 \\
\hline $\begin{array}{c}\text { Property, } \\
\text { plant and } \\
\text { equipment, net }\end{array}$ & 22,118 & 26,576 & 30,482 & $\begin{array}{l}\text { Long-term debt } \\
\text { and finance leases }\end{array}$ & 20,278 & 19,931 & 21,818 \\
\hline $\begin{array}{c}\text { Operating } \\
\text { lease right-of- } \\
\text { use assets }\end{array}$ & - & - & 2,856 & $\begin{array}{l}\text { Non-current } \\
\text { operating leases }\end{array}$ & - & - & 2,391 \\
\hline Goodwill & 3,872 & 3,811 & 3,813 & $\begin{array}{l}\text { Pension and } \\
\text { postretirement } \\
\text { benefit obligations }\end{array}$ & 7,061 & 8,347 & 10,601 \\
\hline $\begin{array}{l}\text { Intangible } \\
\text { assets, net }\end{array}$ & 1,964 & 2,075 & 2,167 & $\begin{array}{l}\text { Deferred income } \\
\text { tax liabilities }\end{array}$ & 756 & 1,619 & 1,632 \\
\hline $\begin{array}{c}\text { Investments } \\
\text { and restricted } \\
\text { cash }\end{array}$ & 483 & 170 & 24 & $\begin{array}{l}\text { Self-Insurance } \\
\text { reserves }\end{array}$ & 1,765 & 1,571 & 1,282 \\
\hline $\begin{array}{l}\text { Deferred } \\
\text { income tax } \\
\text { assets }\end{array}$ & 266 & 141 & 330 & $\begin{array}{l}\text { Other non-current } \\
\text { liabilities }\end{array}$ & 1,804 & 1,424 & 1,437 \\
\hline \multirow[t]{3}{*}{$\begin{array}{c}\text { Other non- } \\
\text { current assets }\end{array}$} & 1,153 & 1,033 & - & & & & \\
\hline & & & & $\begin{array}{l}\text { III Shareholders' } \\
\text { equity }\end{array}$ & 1,024 & 3,037 & 3,283 \\
\hline & & & & $\begin{array}{l}\text { Total equity } \\
\text { for controlling } \\
\text { interests }\end{array}$ & 994 & 3,021 & 3,267 \\
\hline
\end{tabular}




\begin{tabular}{|r|r|r|r|l|r|r|r|}
\hline & & & $\begin{array}{l}\text { Noncontrolling } \\
\text { interests }\end{array}$ & 30 & 16 & 16 \\
\hline Total & $\mathbf{4 5 , 5 7 4}$ & $\mathbf{5 0 , 0 1 6}$ & $\mathbf{5 7 , 8 5 7}$ & Total & $\mathbf{4 5 , 5 7 4}$ & $\mathbf{5 0 , 0 1 6}$ & $\mathbf{5 7 , 8 5 7}$ \\
\hline
\end{tabular}

Source: UPS, Annual Reports 2017, 2018, 2019

The consolidated income statement (Table 2) is used for obtaining financial information about key positions needed to calculate human capital efficiency indicators. UPS reported annual revenue of \$66,585 million in 2017, \$71,861 million in 2018 and \$74,094 million in 2019, and operating expenses of $\$ 59,056$ million in 2017, $\$ 64,837$ million in 2018 and $\$ 66,296$ million in 2019. Earnings before interest and taxes (EBIT) and earnings before interest, taxes, depreciation and amortization (EBITDA) are essential for this analysis since they are used for the calculation of human capital efficiency indicators. For the fiscal years 2017, 2018, 2019, UPS reported EBIT of \$7,529 million, \$7,024 million and \$7,798 million, while EBITDA had the value of $\$ 9,811$ million $\$ 9,231$ million and $\$ 10,158$ million. The fact is that human capital cannot be calculated without information about salaries of managers and other employees, which represent personal expenses in the consolidated income statement (Table 2).

Table 2. Consolidated Income Statement of UPS as of December 31, 2017, 2018, 2019

\begin{tabular}{|c|c|c|c|c|}
\hline Number & ELEMENTS & $\begin{array}{c}2017 \\
\text { (In \$ } \\
\text { million) }\end{array}$ & $\begin{array}{c}2018 \\
\text { (In \$ million) }\end{array}$ & $\begin{array}{c}2019 \\
\text { (In \$ million) }\end{array}$ \\
\hline 1 & Revenue & 66,585 & 71,861 & 74,094 \\
\hline \multirow[t]{8}{*}{2} & Operating expenses & 59,056 & 64,837 & 66,296 \\
\hline & Salaries & 34,577 & 37,235 & 38,908 \\
\hline & Repairs and maintenance & 1,601 & 1,732 & 1,838 \\
\hline & Depreciation and amortization & 2,282 & 2,207 & 2,360 \\
\hline & Purchased transportation & 11,696 & 13,409 & 12,590 \\
\hline & Fuel & 2,690 & 3,427 & 3,289 \\
\hline & Other occupancy & 1,155 & 1,362 & 1,392 \\
\hline & Other expenses & 5,055 & 5,465 & 5,919 \\
\hline 3 & Operating profit & 7,529 & 7,024 & 7,798 \\
\hline \multirow[t]{3}{*}{4} & Other income and (expense) & (392) & $(1,005)$ & $(2,146)$ \\
\hline & Investment income (expense) and other & 61 & $(400)$ & $(1,493)$ \\
\hline & Interest expense & $(453)$ & $(605)$ & $(653)$ \\
\hline 5 & Income before income taxes & 7,137 & 6,019 & 5,652 \\
\hline 6 & Income tax expense & 2,232 & 1,228 & 1,212 \\
\hline 7 & Net income & 4,905 & 4,791 & 4,440 \\
\hline 8 & EBIT (Earnings before interest and taxes) & 7,529 & 7,024 & 7,798 \\
\hline 9 & EBITDA (EBIT+ depreciation + amortization) & 9,811 & 9,231 & 10,158 \\
\hline
\end{tabular}

Source: UPS, Annual Reports 2017, 2018, 2019

To obtain indicators of human capital efficiency, it is necessary to gather additional information. To calculate HCMV, information about market capitalization is required. According to the financial information about the number of shares and market price per share of UPS, the market capitalization amounts $\$ 105,498.75$ million in 2017 , $\$ 84,459.60$ million in 2018 and $\$ 101,142.91$ million in 2019 (Table 3). To present the 
whole amount of human capital, the total sum of stimulatory incentives is added to the amount of personal expenses (Table 3). The value of human capital at UPS is $\$ 34,607.98$ million in 2017, $\$ 37,271.20$ million in 2018 and $\$ 38,953.90$ million in 2019 . To calculate Ehc, the value of ICVA (EBITDA + Hc) is required, which amounts \$44,418.98 million in 2017, \$46,502.20 million and \$49,111.90 million in 2019.

Efficiency in the use of human capital (Ehc) shows us how many monetary units of ICVA are generated for each monetary unit of human capital. In our example, every dollar of human capital generates $\$ 1.28349$ of ICVA in 2017. A slight decline in the value of the indicator could be noticed in 2018, and in 2019 the value of the indicator increased slightly, but it is still at a lower level than in 2017.

Human capital cost factor ( $\mathrm{HCCF}$ ) shows the absolute sum of total costs related to employees and managers. Given that in our example this indicator is equal to the value of human capital, we will observe the indicator human capital cost factor per employee. For the period from 2017-2019, a slight increase in the total cost of human capital per employee could be noticed, from \$0.07623 in 2017 to \$0.07869 in 2019.

Table 3. Indicators of Human Capital Efficiency in UPS for 2017, 2018 and 2019

\begin{tabular}{|l|l|r|r|r|}
\hline Number & \multicolumn{1}{|c|}{ ELEMENTS } & $\mathbf{2 0 1 7}$ & $\mathbf{2 0 1 8}$ & \multicolumn{2}{c|}{$\mathbf{2 0 1 9}$} \\
\hline 1 & Number of shares & 875 & 870 & 869 \\
\hline 2 & Market price per share & 120.57 & 97.08 & 116.39 \\
\hline 3 & Mc $(1 x 2)$ & $105,498.75$ & $84,459.60$ & $101,142.91$ \\
\hline 4 & As & 45,574 & 50,016 & 57,857 \\
\hline 5 & $E=A s-L-N c i$ & 994 & 3,021 & 3,267 \\
\hline 6 & AIC $(3-5)$ & $104,504.75$ & $81,438.60$ & $97,875.91$ \\
\hline 7 & Iag & 5,836 & 5,886 & 5,980 \\
\hline 8 & IC $(6+7)$ & $110,340.75$ & $87,324.60$ & $103,855.91$ \\
\hline 9 & Personal expenses & 34,577 & 37,235 & 38,908 \\
\hline 10 & The total sum of stimulating incentives & 30.98 & 36.20 & 45.90 \\
\hline 11 & Hc $(9+10)$ & $34,607.98$ & $37,271.20$ & $38,953.90$ \\
\hline 12 & EBIT & 7,529 & 7,024 & 7,798 \\
\hline 13 & EBITDA & 9,811 & 9,231 & 10,158 \\
\hline 14 & Number of employees & 454,000 & 481,000 & 495,000 \\
\hline 15 & ICVA $(11+13)$ & $44,418.98$ & $46,502.20$ & $49,111.90$ \\
\hline 16 & Ehc & 1.28349 & 1.24767 & 1.26077 \\
\hline 17 & HCCF per employee & 0.07623 & 0.07749 & 0.07869 \\
\hline 18 & HCMV & 0.00001 & 0.00000 & 0.00000 \\
\hline 19 & HCVA & 0.09281 & 0.09209 & 0.09445 \\
\hline 20 & HCROI & 1.21755 & 1.18846 & 1.20019 \\
\hline
\end{tabular}

Note: the data from Annual Reports 2017, 2018, 2019 and Proxy Statements 2018, 2019, 2020 of UPS is used for the calculation

Human capital market value (HCMV) shows how much each employee contributes to the formation of the value of the Mc / As indicator. In our case, it could be said that each employee contributes $\$ 0.00001$ to the formation of the value of the $\mathrm{Mc} /$ As indicator in 2017 . Given that UPS has a large number of employees, we cannot ignore this indicator, although at first glance it seems that employees do not make a large contribution to the formation of the value of Tobin's Q. 
Human capital value added (HCVA) shows how many dollars of value added (which is calculated as the sum of EBIT and Hc) each employee generates. In our example, this indicator shows that each employee generates $\$ 0.09281$ of value added in 2017 . Although the value of the indicator fell slightly in 2018, we could notice an increase in the indicator in 2019 compared to both previous years.

Human capital return on investment (HCROI) shows the return on 1 dollar of investment in human capital. In our example, for every dollar invested in human capital, we have a return of $\$ 1.21755$ in 2017 . We could notice a slight decline in the value of the indicator in 2018. Although the value of the indicator increases in 2019, it is still lower than in 2017.

\section{Conclusion}

The knowledge economy marks an era in which human and other intellectual resources play a key role in creating value. Unlike the knowledge era, in the industrial era physical and financial resources were the crucial value creators. As a result, human capital is crucial for the growth, productivity and overall efficiency of an enterprise. Human capital measurement is important for better management of employees' natural characteristics, capabilities and skills. Human capital's uniqueness is demonstrated by the fact that its components are oneof-a-kind and impossible for rivals to emulate. Due to specific features of human capital, the measurement of human capital can be challenging and complicated. Therefore, there is a need for developing a new framework of human capital measurement indicators, which makes a step forward comparing to traditional indicators of labour productivity. The new framework would contain a series of new indicators that will allow better control of efficiency in the use of human capital. Different and numerous metrics could be used when determining the efficiency of human capital. Connecting them is needed to depict the actual situation in the company and is thus critical to the successful evaluation of the whole entity. The human capital efficiency measurement with such a framework of new indicators allows managers to use more efficiently the capacities of human capital in their enterprises. The conclusion is that all managers should consider using a broader set of human capital efficiency indicators for better management of human capital.

\section{References}

Abasilim, A.N. \& Agboola, A.A. (2013). Measurement of human capital performance in organizations: issues and challenges. Jorind, 11(2), 73-79.

Annual report 2017 of UPS. Retrieved December 21, 2020 from http://www.investors. ups.com/static-files/469f785d-5c5d-4c95-9b2e-3151de31a8c6

Annual report 2018 of UPS. Retrieved December 21, 2020 from http://www.investors. ups.com/static-files/36277c15-d055-4147-b150-f3d0d8f35996

Annual report 2019 of UPS. Retrieved December 21, 2020 from http://www.investors. ups.com/static-files/e4d06ff9-8dcd-45a7-a8f5-b400c944455e

Bagieńska, A. (2015). Measurement and analysis of the efficiency of human capital in a small enterprise in Poland. Financial Internet Quarterly e-Finanse, 11(2), 1-9.

Baron, A. (2017). Measuring human capital. Strategic HR Review, 10 (2), 30-35. 
Black, S. E. \& Lynch, L. M. (1996). Human-capital investments and productivity. American Economic Review, 86(2), 263-267.

Bontis, N. \& Fitz-enz, J. (2002). Intellectual capital ROI: a causal map of human capital antecedents and consequents. Journal of Intellectual Capital, 3(3), 223247.

Borowski, A. (2015). Methods of human capital measurement. Managing Intellectual Capital and Innovation for Sustainable and Inclusive Society, Italy, 571-577.

Buhner R. (1997) Increasing shareholder value through human asset management. Long Range Planning, 30(5), 710-717.

Campbell, B.A., Coff, R. \& Kryscynski, D. (2012). Rethinking sustained competitive advantage from human capital. Academy of Management Review, 37, 376-395.

Cascio, W.F. (2010). Managing human resources - productivity, quality of work life, profits. (8th edition). New York: McGraw-Hill.

Chan, K.H. (2009). Impact of intellectual capital on organizational performance. The Learning Organization, 16, 4-21.

Chen, H.M., \& Lin, K.J. (2004). The role of human capital cost in accounting. Journal of Intellectual Capital, 5(1), 116-130.

Chen, M.C., Cheng, S.J. \& Hwang, Y. (2005). An empirical investigation of the relationship between intellectual capital and firms' market value and financial performance. Journal of Intellectual Capital, 6(2), 159-176.

Drábek, J., Lorincová, S. \& Javorcíková, J. (2017). Investing in human capital as a key factor for the development of enterprises. IntechOpen: Issues of Human Resource Management.

Durrani, T.S. \& Forbes, S.M. (2003). Intellectual capital and technology strategy. IEMC '03 Proceedings - Managing technologically driven organizations: The human side of innovation and change, pp. 151-155.

Dženopoljac, V. (2013). The impact of intangible assets of a company on the value creation process. Doctoral dissertation, Kragujevac: University of Kragujevac, Faculty of Economics.

Fitz-enz, J. (2000). The ROI of human capital: measuring the economic value of employee performance. New York: AMACOM.

Fitz-enz, J. (2010). The new HR analytics. Predicting the economic value of your company's human capital investments. New York: American Management Association.

Folloni, G. \& Vittadini, G. (2010). Human capital measurement: a survey. Journal of Economic Surveys 24, 248-279.

Ghosh, S. \& Mondal, A. (2009). Indian software and pharmaceutical sector IC and financial performance. Journal of Intellectual Capital, 6(3), 369-88.

Giménez, G., López, P.C. \& Sanaú, J. (2015). Human capital measurement in OECD countries and its relation to GDP growth and innovation. Revista de Economía Mundial, 39, 77-107.

Kamath, B.G. (2007). Intellectual capital performance of Indian banking sector. Journal of Intellectual Capital, 8(1), 96-123.

Kozińska, A.M. (2003). Wartość przedsiębiorstwa a kapitał ludzki. In Dobija D. (Ed.), Pomiar i rozwój kapitału ludzkiego przedsiębiorstwa. Warszawa: Polska Fundacja Promocji Kadr. 
Krstić B. (2007) Upravljanje performansama ljudskih resursa kao determinanta kreiranja vrednosti i konkurentske prednosti preduzeća. Teme, 2, 315-328.

Krstić, B. \& Sekulić V. (2020) Upravljanje poslovnim performansama. Niš: Faculty of Economics, University of Niš.

Krstić, B., \& Bonić, Lj. (2016). EIC: A new tool for intellectual capital performance measurement. Prague Economic Papers, 25(6), 1-18.

Kucharčíková, A., Tokarčíková, E. \& Ďurišová, M. (2015). Human capital efficiency in trading company. Prague: The 9th International Days of Statistics and Economics.

Kujansivu, P., Lönnqvist, A., Jääskeläinen, A. \& Sillanpää, V. (2007). Liiketoiminnan ai-neettomat menestystekijät. Talentum, Helsinki, 1st Edition.

Lindenberg, E. \& Ross, S. (1981). Tobin's Q ratio and industrial organization. The Journal of Business, 54, 1-32.

Marcinkowska, M. (2004). Roczny raport z działań $i$ wyników przedsiębiorstwa. Kraków: Oficyna Ekonomiczna.

Mauterer, H. \& Wengel, A. (2019). Human capital reporting ISO 30414 consulting services. Retrieved December 21, 2020 from https://lp.4cgroup.com/ international-guideline-for-human-capital-reporting.

Meszek, W. (2015). Measurement of human capital in the specificity of a construction enterprise. Procedia Engineering, 122, 213-219.

Naden, C. (2019). New ISO international standard for human capital reporting. Retrieved December 21, 2020 from https://www.iso.org/news/ref2357.html.

Nafukho, F. M., Hairston, N. R., \& Brooks, K. (2004). Human capital theory: implications for human resource development. Human Resource Development International, 7(4), 545-551.

Ocean Tomo LLC. (2020). Intangible Assets Market Value Study. Retrieved February 21, 2021 from https://www.oceantomo.com/intangible-asset-market-value-study/.

Oviedo-Garcia, M. A., Castellanos-Verdugo, M., Garcia Del Junco, J. \& Riquelme Miranda, A. (2014). Organizational learning capacity and its impact on the results in a government agency in Chile. International Public Management Journal, 17(1), 74-110.

Pocztowski, A. (2003). Zarzadzanie zasobami ludzkimi: strategie, procesy, metody. Warszawa: Polskie Wydawnictwo Ekonomiczne.

Porter, M.E. \& Stern, S. (2001). Innovation: location matters. MIT Sloan Management Review, 42, 28-36.

Price, A. (2011). Human resource management. South Western CENGAGE Learning, United Kingdom.

Proxy statement 2018 of UPS. Retrieved December 21, 2020 from http://www. investors.ups.com/static-files/1ad31e8b-ecb5-4f96-8218-f4d141052a6e

Proxy statement 2019 of UPS. Retrieved December 21, 2020 from http://www. investors.ups.com/static-files/115b9ccc-f383-4ecb-b220-75a1e79c0f02

Proxy statement 2020 of UPS. Retrieved December 21, 2020 from http://www. investors.ups.com/static-files/6cf5536a-0574-449d-bde3-f4c09139a2de

Pulić, A. (2000). VAIC ${ }^{\mathrm{TM}}$ - an accounting tool for IC management. International Journal of Technology Management, 20(5-8), 702-714. 
Rahim, A., Atan, R. \& Kamaluddin, A. (2017). Human capital efficiency and firm performance: an empirical study on Malasian technology industry. SHS Web of Conferences.

Ruchala, L.V. (1997). Managing and controlling. Management Accounting - New York, $79,20-27$.

Sajkiewicz, A. (2002). Jakość zasobów pracy: kultura, kompetencje, konkurencyjność: praca zbiorowa. Warszawa: Poltext.

Scholz, C., Stein, V. \& Bechtel, R. (2011). Human capital management: Raus aus der Unverbindlichkeit. $3^{\text {rd }}$ ed., Cologne: Luchterhand. 
